\title{
Pentoxifylline and Covid-19: A Systematic Review
}

\author{
Diego Ramonfaur, MD ${ }^{1,2}$, Carlos A. González-Assad, MD¹ , José G. Paredes-Vázquez, MD ${ }^{1}$ \\ ${ }^{1}$ Instituto de Cardiología y Medicina Vascular, Escuela de Medicina y Ciencias de la Salud. \\ Monterrey, Mexico. \\ ${ }^{2}$ School of postgraduate education, Harvard Medical School, Boston, MA. \\ ORCIDs \\ Diego Ramonfaur 0000-0003-3884-149X \\ Carlos A. González 0000-0001-7851-9660 \\ José G. Paredes 0000-0002-6895-8026
}

Corresponding author: Diego Ramonfaur

Email: dramonfaur@hms.harvard.edu

Address: 25 Shattuck St, Boston, MA 02115, United States

Contribution statement: All authors substantially contributed to the conception and interpretation of the work. All authors revised the manuscript for important intellectual content. All authors gave final approval of the version to be published.

The authors declare no conflict of interest

This study did not request or receive any funding.

Key Words: Pharmacology, respiratory diseases, infectious diseases, COVID-19, systematic review

Word count: 2,910 


\begin{abstract}
At more than 10 months after the first case of COVID-19 was documented, the understanding of the pathogenesis of this viral illness is growing on a daily basis. A massive proinflammatory response on infected individuals involving several cytokines seems to play a key role on disease. As a result, therapeutic efforts have focused on anti-inflammatory strategies to ameliorate the disease, in sight of a lack of a truly effective anti-viral agent. Pentoxifylline (PTX) has been proposed by multiple authors as a potential therapeutic ally, targeting a variety of mechanisms as it has been shown to have antiviral, anti-inflammatory and hemodynamic effects. Importantly, anti-inflammatory effects center on down-regulation of cytokines such as interleukins and tumor necrosis factor. In pre-pandemic studies, PTX has demonstrated to change the clinical course of inflammatory diseases such as acute respiratory distress syndrome, which is a hallmark of severe COVID-19. Researchers agree it is pertinent to experimentally evaluate the effect this drug has on COVID-19 patients. The objective of this review is to summarize all the proposed mechanisms by which PTX may aid in the treatment of COVID-19, as well as prevent its deadly complications. Our interpretation of the literature is that the benefits PTX may bring to a patient with COVID-19 outweigh the risks this drug might pose on them. As a result, there is consensus regarding the evaluation of PTX in further experimental studies to better characterize its effects on COVID-19 patients.
\end{abstract}

\title{
INTRODUCTION
}

In late 2019, the Severe acute respiratory syndrome coronavirus 2 (SARS-CoV-2) emerged in Wuhan, China, presumably as a zoonotic infection originating from bats.(1) This virus, which causes the coronavirus disease 19 (COVID-19), rapidly expanded worldwide, as travel restrictions failed to optimally control the spread. As of January $21^{\text {st }}$, the first case of COVID-19 was identified in the United States. Recent experience with viral respiratory epidemics with similar characteristics was limited to SARS and MERS outbreaks, as well as the 2009 H1N1 pandemic. However, it has a slightly higher rate of transmission than these viruses, and shares almost $80 \%$ of its genome with SARS-CoV.(1,2) As major pharmaceutical companies and research efforts race to find an effective therapeutic agent, many anti-viral medications were quickly tested and discarded from the list of potential medications with the exception of remdesivir, which has demonstrated a reduction in symptom duration, but is still reserved for severe cases. (3). It has been well described that a subset of patients may develop coagulopathy, as a result of the cytokine storm mediated amid an aggressive inflammatory response to the SARS-CoV-2, ultimately leading to complications like acute respiratory distress syndrome (ARDS).(4) As a result, investigators have proposed alternative drugs with multiple mechanisms of action in light of finding a lower rate of complications from this disease, and potentially lower the mortality. Pentoxifylline (PTX) is a methylxanthine derivative, currently used for peripheral vascular disease, with anti-inflammatory and immunomodulatory properties(5-7). Moreover, the main pharmacodynamic properties of this drug are aimed at improving circulation by increasing erythrocyte deformability.(8) Additionally, a safe side effect profile, and a low cost make PTX a strong candidate to be considered as an aid in the treatment for high risk COVID-19 patients. This drug was initially proposed as an alternative treatment for the SARS outbreak in 2003. Subsequently, there has been some attention to this drug as the COVID-19 pandemic began to 
spread. Accordingly, no published study has analyzed the clinical impact of utilizing this drug as a potential therapeutic agent. The purpose of this study is to systematically gather all the latest evidence on pentoxifylline as a potential treatment for COVID-19 and analyze the feasibility of further trials as well as trends in treatment strategies.

\section{METHODS}

Currently, no systematic review of the literature looking at the use of pentoxifylline as a potential treatment for COVID-19 has been published. The PROSPERO database was revised, and no study of this characteristics was found. We sought to identify all scientific literature analyzing the potential benefits of pentoxifylline against COVID-19. We queried Pubmed and Google scholar search engines utilizing the following commands: (Pentoxifylline AND COVID), (Pentoxifylline AND Coronavirus), and (Pentoxifylline AND SARS). For obvious reasons, only publications from 2020 were considered. There was no language limitation. Only published manuscripts were eligible. Information regarding potential mechanisms of action of Pentoxifylline against COVID-19 and its complications was extracted. This systematic review is structured using the PRISMA guidelines.

\section{RESULTS}

A total of 11 studies were found using the described methodology. One study which was a clinical trial proposal preprint was excluded. We identified a total of 8 research items eligible for our review which are summarized in table 1 . No experimental study was found.

\begin{tabular}{|c|c|c|c|c|}
\hline Title & Author & $\begin{array}{l}\text { Relevant proposed } \\
\text { mechanisms }\end{array}$ & Conclusions & $\begin{array}{l}\text { Favors } \\
\text { the use } \\
\text { of } \\
\text { PTX? }\end{array}$ \\
\hline $\begin{array}{l}\text { COVID-19: Older } \\
\text { drugs for a novel } \\
\text { disease- } \\
\text { Chloroquine, } \\
\text { hydroxychloroquine, } \\
\text { and possible } \\
\text { Pentoxifylline (9) }\end{array}$ & $\begin{array}{l}\text { Pugazhenthan } \\
\text { Thangaraju }\end{array}$ & $\begin{array}{l}\text { PDE-4 inhibition. } \\
\text { Down regulation of NF kappa B } \\
\text { and NFAT transcription factors. }\end{array}$ & $\begin{array}{l}\text { The anti-inflammatory and } \\
\text { immunomodulatory actions } \\
\text { of pentoxifylline could play } \\
\text { an important role in the } \\
\text { treatment of the respiratory } \\
\text { distress due to the COVID } \\
19 \text {. }\end{array}$ & Yes \\
\hline $\begin{array}{l}\text { COVID-19: } \\
\text { Pentoxifylline as a } \\
\text { potential adjuvant } \\
\text { treatment (10) }\end{array}$ & Amir Feily & $\begin{array}{l}\text { PDE-4 inhibition. } \\
\text { Suppression of TNF- } \alpha \text { and } \\
\text { modulation of inflammatory } \\
\text { cytokines. }\end{array}$ & $\begin{array}{l}\text { Pentoxifylline, with its } \\
\text { potent anti-inflammatory } \\
\text { effects and therapeutic effect } \\
\text { on pulmonary fibrosis, can } \\
\text { be a potential adjuvant } \\
\text { treatment against COVID- } \\
19 .\end{array}$ & Yes \\
\hline $\begin{array}{l}\text { Harnessing adenosine } \\
\text { A2A receptors as a } \\
\text { strategy for } \\
\text { suppressing the lung } \\
\text { inflammation and } \\
\text { thrombotic } \\
\text { complications of }\end{array}$ & DiNicolantonio & $\begin{array}{l}\text { Potentiation of the } \\
\text { responsiveness of } \mathrm{A} 2 \mathrm{AR} \\
\text { receptor }(\mathrm{A} 2 \mathrm{AR}) \text { to adenosine. }\end{array}$ & $\begin{array}{l}\text { PTX and DIP potentiate the } \\
\text { signaling activity of } \\
\text { extracellular adenosine and } \\
\text { increase extracellular levels } \\
\text { of adenosine respectively. } \\
\text { The use of PTX with DIP } \\
\text { can be used in advanced }\end{array}$ & Yes \\
\hline
\end{tabular}




\begin{tabular}{|c|c|c|c|c|}
\hline $\begin{array}{l}\text { COVID-19: Potential } \\
\text { of pentoxifylline and } \\
\text { dipyridamole (5) }\end{array}$ & & & $\begin{array}{l}\text { COVID-19, making them a } \\
\text { possibility to improve } \\
\text { outcomes in these patients. }\end{array}$ & \\
\hline $\begin{array}{l}\text { Pentoxifylline is a } \\
\text { potential cytokine } \\
\text { modulator therapeutic } \\
\text { in COVID-19 } \\
\text { patients (11) }\end{array}$ & Hendry & $\begin{array}{l}\text { PDE-4 inhibition. } \\
\text { Down-regulation of TNF- } \alpha \text {, } \\
\text { IL1b, IL6, FN gamma, ICAM1, } \\
\text { and VCAM1. } \\
\text { Down-regulation A2AR. }\end{array}$ & $\begin{array}{l}\text { Pentoxifylline has anti- } \\
\text { inflammatory properties, } \\
\text { including down regulation of } \\
\text { TNF- } \alpha, \text { IL-1b, IL- } 6 \text { and } \\
\text { other cytokines. This can } \\
\text { reduce lung damage in } \\
\text { patients with COVID-19. }\end{array}$ & Yes \\
\hline $\begin{array}{l}\text { Potential usefulness } \\
\text { of pentoxifylline, a } \\
\text { non-specific } \\
\text { phosphodiesterase } \\
\text { inhibitor with anti- } \\
\text { inflammatory, anti- } \\
\text { thrombotic, } \\
\text { antioxidant, and anti- } \\
\text { fibrogenic properties, } \\
\text { in the treatment of } \\
\text { SARS-CoV-2 (12) }\end{array}$ & $\begin{array}{l}\text { González- } \\
\text { Pacheco }\end{array}$ & $\begin{array}{l}\text { Suppression of TNF- } \alpha, \text { IL-1b, } \\
\text { IL-6, IL- } 8 \text {, and CRP } \\
\text { production. } \\
\text { Increase in levels of IL-10. } \\
\text { Inhibition of T cell and natural } \\
\text { killer cell cytotoxicity. } \\
\text { Inhibition of surface expression } \\
\text { of intracellular adhesion } \\
\text { molecule } 1 \text { and the production } \\
\text { of IL-8 and monocyte } \\
\text { chemoattractant protein-1. } \\
\text { Suppression of neutrophil } \\
\text { activation. } \\
\text { Reduction of plasma } \\
\text { fibrinogen. }\end{array}$ & $\begin{array}{l}\text { PTX has anti-inflammatory, } \\
\text { anti-thrombotic, rheological, } \\
\text { antioxidant and anti- } \\
\text { fibrogenic properties might } \\
\text { help to prevent or mitigate } \\
\text { the inflammatory response } \\
\text { and occlusive thrombotic } \\
\text { events, thereby decreasing } \\
\text { multi-organ dysfunction and } \\
\text { acute lung injury. This } \\
\text { suggests it could be a } \\
\text { valuable adjuvant treatment } \\
\text { in patients with COVID-19. }\end{array}$ & Yes \\
\hline $\begin{array}{l}\text { Repositioning of } \\
\text { pentoxifylline as an } \\
\text { immunomodulator } \\
\text { and regulator of the } \\
\text { renin-angiotensin } \\
\text { system in the } \\
\text { treatment of COVID- } \\
\text { 19. (13) }\end{array}$ & Maldonado & $\begin{array}{l}\text { PDE inhibition. } \\
\text { Modulation of IFN- } \gamma \text {, ICAM-1, } \\
\text { VCAM, CRP and AT1R. } \\
\text { Inhibition of TNF- } \alpha \text { production } \\
\text { by alveolar macrophages. } \\
\text { Blockage of TGF-b1 and } \\
\text { prevention of type-1 collagen } \\
\text { deposition. } \\
\text { Decrease in expression levels of } \\
\text { fibronectin and PAI-1 }\end{array}$ & $\begin{array}{l}\text { Various mechanisms of PTX } \\
\text { are potential targets to treat } \\
\text { COVID-19. It's anti- } \\
\text { inflammatory properties, } \\
\text { along with its mechanism to } \\
\text { regulate fibrosis and } \\
\text { modulate the renin- } \\
\text { angiotensin-aldosterone } \\
\text { syndrome make this drug a } \\
\text { reasonable and ethical } \\
\text { candidate for attempting a } \\
\text { new treatment strategy. }\end{array}$ & Yes \\
\hline $\begin{array}{l}\text { Treatment of } \\
\text { COVID-19 with } \\
\text { pentoxifylline: Could } \\
\text { it be a potential } \\
\text { adjuvant therapy? } \\
\text { (14) }\end{array}$ & Seirafianpour & $\begin{array}{l}\text { PDE-4 inhibition. } \\
\text { Decreases leukocyte adhesion } \\
\text { to the endothelium. } \\
\text { Inhibition of activity of T and B }\end{array}$ & $\begin{array}{l}\text { PTX is efficient in } \\
\text { improving end organ } \\
\text { damage involving the heart, } \\
\text { kidney, liver, and brain. PTX } \\
\text { helps control sepsis and } \\
\text { lower its mortality in adults. }\end{array}$ & Yes \\
\hline
\end{tabular}




\begin{tabular}{|c|c|c|c|c|}
\hline & & $\begin{array}{l}\text { lymphocytes. } \\
\text { Increase in collagenase in } \\
\text { fibroblasts. } \\
\text { Decrease in production of } \\
\text { collagen, fibronectin and } \\
\text { glycosaminoglycan. } \\
\text { Increase in prostacyclin } \\
\text { synthesis, plasminogen } \\
\text { activators, plasmin and } \\
\text { antithrombin. } \\
\text { Decrease in fibrinogen, platelet } \\
\text { aggregation, } \alpha 2 \text {-antiplasmin, } \alpha 1 \\
\text { antitrypsin, and } \alpha 2 \\
\text { macroglobulin and } \\
\text { thromboxane. }\end{array}$ & $\begin{array}{l}\text { PTX is functionally } \\
\text { classified as an immune } \\
\text { modulator or immune } \\
\text { booster rather than an } \\
\text { immunosuppressive, which } \\
\text { is very helpful in the case of } \\
\text { COVID-19 infection. }\end{array}$ & \\
\hline $\begin{array}{l}\text { Pentoxifylline: An } \\
\text { Immunomodulatory } \\
\text { Drug for the } \\
\text { Treatment of } \\
\text { COVID-19 (15) }\end{array}$ & Dhameliya & $\begin{array}{l}\text { Inhibit the actions of PDE, IL- } \\
1, \text { TNF- } \alpha \text {, and TNF- } \beta, \text { NF- } \kappa \beta \text {. } \\
\text { Reduces expression of ICAM- } \\
1, \text { IL- } 8 \text { and MCP-1 }\end{array}$ & $\begin{array}{l}\text { PTX reduces cytokine } \\
\text { production, immune cell } \\
\text { migration, and suppress } \\
\text { signal transduction } \\
\text { pathways, minimizing } \\
\text { inflammatory damage in the } \\
\text { lung tissues. }\end{array}$ & Yes \\
\hline
\end{tabular}

Table 1: Summary of articles proposing pentoxifylline as a potential treatment strategy for COVID-19 patients. PDE-4: Phosphodiesterase-4, TNF- $\alpha$ : Tumor Necrosis Factor alpha, TNF- $\beta$ : Tumor Necrosis Factor beta, DIP: Dipyridamole, IL-1: Interleukin-1, IL-1b: Interleukin-1 beta, IL-6: Interleukin-6, IL-8: Interleukin-8, IL-10: Interleukin-10, NF- $\beta$ : Nuclear Factor kappa beta, ICAM-1: Intercellular adhesion molecule 1, VCAM-1: Vascular cell adhesion molecule 1, NFAT: Nuclear factor of activated T-cells, MCP-1: Monocyte Chemoattractant Protein-1, PAI-1: Plasminogen activator inhibitor-1, TGF- $\beta 1$ : Transforming growth factor beta 1, IFN-y: Interferon gamma, CRP: C-reactive protein, AT1R: Angiotensin II type 1 receptor, A2AR: Adenosine A2A receptor, STAT3: Signal transducer and activator of transcription 3

\section{DISCUSSION}

COVID-19 illness is a virus-mediated syndrome which may develop a host cytokine storm. This pro-inflammatory response plays a key role in the damage viral infections cause on a host and may correlate with worse outcomes. There is growing evidence suggesting a subset of these patients are at risk of developing devastating complications such as myocarditis, acute respiratory distress syndrome (ARDS), acute kidney injury, and coagulopathy, among others. These complications are associated with a significant rate of morbidity and mortality, especially in patients with comorbidities, non-white race or in poverty. (16-19) Attempts to find an effective antiviral drug have been futile. The conventional antiviral drug, remdesivir seems to have a potential benefit, although there is mixed evidence regarding its effectiveness in reducing mortality and length of stay. $(3,20)$ It has been shown that most of the dangerous complications 
are due to an overt inflammatory response by the host, rather than viral cytotoxicity by itself. A certain degree of inflammation is necessary to eliminate any kind of infection. However, it has been shown that persistent elevations of pro-inflammatory cytokines are associated with worst outcomes in patients with ARDS. (21) SARS-CoV-2 induces excessive and prolonged cytokine responses in some individuals, known as the cytokine storm. It is this exaggerated response, that may trigger multiple organ dysfunction. (4) As a result, immunomodulatory and antiinflammatory drugs have received attention as potential mitigators of severe COVID-19. Some specific drugs immune modulator drugs with diverse mechanisms of action have the ability to attenuate the cytokine storm. Particularly, steroids such as dexamethasone, and interleukin antagonists like tocilizumab, and anakinra, among others, have received attention as treatment strategies for the hyperinflammatory response. (22,23) A recent study by the RECOVERY collaborative group, found a mortality reduction of $17 \%$ in the treatment arm with daily $6 \mathrm{mg}$ of dexamethasone for 10 days in hospitalized COVID-19 patients. (24)

Pentoxifylline has demonstrated anti-inflammatory, anti-thrombotic, immunomodulatory, hemodynamic, and antiviral properties which makes it a valuable candidate for consideration as alternative or complementary treatment for patients with moderate to severe symptoms. Modulation of TNF- $\alpha$, IL1, IL6, ICAM1, VCAM1 and TNF, as well as inactivation of PDE and prevention of platelet aggregation are among the proposed mechanisms that could aid as treatment options for moderate to severe COVID-19 patients. $(5,6,8,13,25,26)$ PTX has proven to be useful in patients with ARDS, from different etiologies and to improve pulmonary function and control pulmonary fibrosis. (27-29), Furthermore, the potential of pentoxifylline as a therapeutic agent is warranted as there is little to no downside in using this drug because of a safe adverse effect profile and a low cost.

Amid an urge for an effective treatment with a positive effect on morbidity and mortality, hundreds of drugs have been proposed as treatment strategies. This review summarizes the best available evidence showing potential benefits of using PTX as a broad-spectrum treatment mainly aimed at preventing and treating the pro-inflammatory complications of COVID-19. Limitations in our study include that no statistical analysis could be made, as no tangible evidence has been published to date.

\section{CONCLUSION}

Our interpretation of the available literature is that there is ample evidence suggesting a wide portfolio of mechanisms through which PTX may be beneficial in the treatment of COVID19. As a result, we believe PTX has a well-suited profile to prevent and treat potential COVID19-associated complications. Moreover, it's low cost and minimal adverse effects make it a safe drug to consider for pilot clinical trial studies. We encourage researchers to study the clinical benefit of this drug in moderate to severe COVID-19 patients.

\section{REFERENCES}


1. Zhou P, Yang X-L, Wang X-G, Hu B, Zhang L, Zhang W, et al. A pneumonia outbreak associated with a new coronavirus of probable bat origin. Nature. 2020 Mar;579(7798):2703.

2. Liu Y, Gayle AA, Wilder-Smith A, Rocklöv J. The reproductive number of COVID-19 is higher compared to SARS coronavirus. J Travel Med. 2020 Mar 13;27(2):taaa021.

3. Wang Y, Zhang D, Du G, Du R, Zhao J, Jin Y, et al. Remdesivir in adults with severe COVID-19: a randomised, double-blind, placebo-controlled, multicentre trial. The Lancet. 2020 May;395(10236):1569-78.

4. Ye Q, Wang B, Mao J. The pathogenesis and treatment of the 'Cytokine Storm' in COVID19. J Infect. 2020 Jun;80(6):607-13.

5. DiNicolantonio JJ, Barroso-Aranda J. Harnessing adenosine A2A receptors as a strategy for suppressing the lung inflammation and thrombotic complications of COVID-19: Potential of pentoxifylline and dipyridamole. Med Hypotheses. 2020 Oct;143:110051.

6. Chen Y-M, Wu K-D, Tsai T-J, Hsieh B-S. Pentoxifylline Inhibits PDGF-induced Proliferation of and TGF- -stimulated Collagen Synthesis by Vascular Smooth Muscle Cells. $1999 ; 11$.

7. Hood SC, Moher D. Management of intermittent claudication with pentoxfylline: metaanalysis of randomized controlled trials. CAN MED ASSOC J. 1996;7.

8. Ward A, Clissold SP. Pentoxifylline: A Review of its Pharmacodynamic and Pharmacokinetic Properties, and its Therapeutic Efficacy. Drugs. 1987 Jul;34(1):50-97.

9. Thangaraju P, Gurunthalingam M, Varthya S, Venkatesan S, Thangaraju E. COVID-19: Older drugs for a novel disease - Chloroquine, hydroxychloroquine, and possible Pentoxifylline—-set to start the second innings? J Fam Med Prim Care. 2020;9(5):2172.

10. Feily A, Daneshpay K, Alighadr A. COVID-19: Pentoxifylline as a potential adjuvant treatment. Int J Clin Pharmacol Ther. 2020 Jul 1;58(07):406-7.

11. Hendry BM, Stafford N, Arnold AD, Sangwaiya A, Manglam V, Rosen SD, et al. Hypothesis: Pentoxifylline is a potential cytokine modulator therapeutic in COVID $\square 19$ patients. Pharmacol Res Perspect [Internet]. 2020 Aug [cited 2020 Aug 11];8(4). Available from: https://onlinelibrary.wiley.com/doi/abs/10.1002/prp2.631

12. González-Pacheco H, Amezcua-Guerra LM, Sandoval J, Arias-Mendoza A. Potential usefulness of pentoxifylline, a non-specific phosphodiesterase inhibitor with antiinflammatory, anti-thrombotic, antioxidant, and anti-fibrogenic properties, in the treatment of SARS-CoV-2. 2020;3. 
13. Maldonado V, Loza-Mejía MA, Chávez-Alderete J. Repositioning of pentoxifylline as an immunomodulator and regulator of the renin-angiotensin system in the treatment of COVID19. Med Hypotheses. 2020 Nov; 144:109988.

14. Seirafianpour F, Mozafarpoor S, Fattahi N, Sadeghzadeh $\square$ Bazargan A, Hanifiha M, Goodarzi A. Treatment of COVID $\square 19$ with pentoxifylline: Could it be a potential adjuvant therapy? Dermatol Ther [Internet]. 2020 Jun 26 [cited 2020 Aug 11]; Available from: https://onlinelibrary.wiley.com/doi/abs/10.1111/dth.13733

15. A. Dhameliya H, R. Thakkar V, N. Trivedi G, N. Mesara S, B. Subramanian R. Pentoxifylline: An Immunomodulatory Drug for the Treatment of COVID-19. J Pure Appl Microbiol. 2020 May 30;14(suppl 1):861-7.

16. Kim MK, Jeon J-H, Kim S-W, Moon JS, Cho NH, Han E, et al. The Clinical Characteristics and Outcomes of Patients with Moderate-to-Severe Coronavirus Disease 2019 Infection and Diabetes in Daegu, South Korea. Diabetes Metab J. 2020;44:e47.

17. Montero F, Martínez-Barrio J, Serrano-Benavente B, González T, Rivera J, Molina Collada J, et al. Coronavirus disease 2019 (COVID-19) in autoimmune and inflammatory conditions: clinical characteristics of poor outcomes. Rheumatol Int [Internet]. 2020 Aug 13 [cited 2020 Aug 15]; Available from: http://link.springer.com/10.1007/s00296-020-04676-4

18. Arasteh K. Prevalence of Comorbidities and Risks Associated with COVID-19 Among Black and Hispanic Populations in New York City: an Examination of the 2018 New York City Community Health Survey. J Racial Ethn Health Disparities [Internet]. 2020 Aug 13 [cited 2020 Aug 15]; Available from: http://link.springer.com/10.1007/s40615-020-00844-1

19. Gu T, Mack JA, Salvatore M, Sankar SP, Valley TS, Singh K, et al. COVID-19 outcomes, risk factors and associations by race: a comprehensive analysis using electronic health records data in Michigan Medicine [Internet]. Infectious Diseases (except HIV/AIDS); 2020 Jun [cited 2020 Aug 15]. Available from: http://medrxiv.org/lookup/doi/10.1101/2020.06.16.20133140

20. Spinner CD, Gottlieb RL, Criner GJ, Arribas López JR, Cattelan AM, Soriano Viladomiu A, et al. Effect of Remdesivir vs Standard Care on Clinical Status at 11 Days in Patients With Moderate COVID-19: A Randomized Clinical Trial. JAMA [Internet]. 2020 Aug 21 [cited 2020 Sep 3]; Available from: https://jamanetwork.com/journals/jama/fullarticle/2769871

21. Meduri GU, Headley S, Kohler G, Stentz F, Tolley E, Umberger R, et al. Persistent Elevation of Inflammatory Cytokines Predicts a Poor Outcome in ARDS. Chest. 1995 Apr;107(4):1062-73.

22. Toniati P, Piva S, Cattalini M, Garrafa E, Regola F, Castelli F, et al. Tocilizumab for the treatment of severe COVID-19 pneumonia with hyperinflammatory syndrome and acute respiratory failure: A single center study of 100 patients in Brescia, Italy. Autoimmun Rev. $2020 \mathrm{Jul} ; 19(7): 102568$. 
23. Dimopoulos G, de Mast Q, Markou N, Theodorakopoulou M, Komnos A, Mouktaroudi M, et al. Favorable Anakinra Responses in Severe Covid-19 Patients with Secondary Hemophagocytic Lymphohistiocytosis. Cell Host Microbe. 2020 Jul;28(1):117-123.e1.

24. The RECOVERY Collaborative Group. Dexamethasone in Hospitalized Patients with Covid19 — Preliminary Report. N Engl J Med. 2020 Jul 17;NEJMoa2021436.

25. Schröer RH. Antithrombotic Potential of Pentoxifylline A Hemorheologically Active Drug. Angiology. 1985 Jun;36(6):387-98.

26. Martín JFB, Jiménez JL, Muńoz-Fernández MÁ. Pentoxifylline and severe acute respiratory syndrome (SARS): a drug to be considered. Med Sci Monit. 2003;7.

27. Wen WX, Lee SY, Siang R, Koh RY. Repurposing Pentoxifylline for the Treatment of Fibrosis: An Overview. Adv Ther. 2017 Jun;34(6):1245-69.

28. Adhikari N, Burns KEA, Meade MO. Pharmacologic Treatments for Acute Respiratory Distress Syndrome and Acute Lung Injury: Systematic Review and Meta-Analysis. Treat Respir Med. 2004;3(5):307-28.

29. Oliveira-Junior IS, Brunialti MKC, Koh IHJ, Junqueira VBC, Salomão R. Effect of pentoxifylline on lung inflammation and gas exchange in a sepsis-induced acute lung injury model. Braz J Med Biol Res. 2006 Nov;39(11):1455-63. 